\title{
The natural foundations of religion
}

\section{Mark Collier}

In the Natural history of religion, Hume attempts to understand the origin of our folk belief in gods and spirits. These investigations are not, however, purely descriptive. Hume demonstrates that ontological commitment to supernatural agents depends on motivated reasoning and illusions of control. These beliefs cannot, then, be reflectively endorsed. This proposal must be taken seriously because it receives support from recent work on our psychological responses to uncertainty. It also compares quite favorably with its main competitors in the cognitive science of religion.

Keywords: Cognitive Science of Religion; Hume; Motivated Reasoning; Natural History of Religion; Positive Illusions; Unwelcome Belief

\section{Introduction}

In the Natural history of religion, ${ }^{1}$ Hume attempts to understand the psychological foundations of our folk belief in gods and spirits. Ontological commitment to supernatural beings is found in almost every culture. What accounts for these widespread beliefs? How did the flora and fauna of religion come to populate the world? Hume approaches these questions as a scientist of human nature. Religion is regarded as an entirely natural phenomenon, and as a result, a subject suitable for experimental investigation. Hume's ambition is to discover the principles of human nature responsible for the culturally recurrent belief in invisible, intelligent agents.

There is much at stake in this project. Hume's investigations are descriptive in character, but they have potentially serious normative consequences. Once we have identified the psychological mechanisms that give rise to our natural religious beliefs, after all, we can proceed to ask whether they can be reflectively endorsed. Hume's verdict on this score, moreover, is entirely negative. He maintains that our folk belief in supernatural agents is derived from untrustworthy processes such as motivated reasoning and illusions of control. Investigating the foundations of these commitments, it seems, generates prima facie doubts about their legitimacy.

Mark Collier is Associate Professor of Philosophy at the University of Minnesota, Morris.

Correspondence to: Mark Collier, University of Minnesota, Morris, 600 E.4th St., Morris, MN 56267, USA.

Email: mcollier@morris.umn.edu 
How can we evaluate the status of these proposals? Hume offers an empirical hypothesis concerning the natural foundations of religion. We must assess its merits, then, in light of our best available evidence. This paper attempts to carry out this task. Section 2 examines Hume's explanation of folk religious belief. Section 3 maintains that his proposals receive a good deal of support from recent work on our psychological responses to uncertainty. Section 4 argues that Hume's theory compares favorably to its main competitors in the cognitive science of religion. The fifth and sixth defend it from objections. The ultimate conclusion of the paper is that Hume's natural history of religion is more plausible than previously recognized; his account should appeal to contemporary researchers, then, who are interested in the foundations of religious belief.

\section{Hume's Natural History of Religion}

Everyday life in our ancestral environment, according to Hume, must have been precarious. The outcomes of significant events—such as harvests, illnesses, and wars-were full of uncertainty (NHR, p. 139). How did our primitive ancestors respond in these circumstances? Hume maintains that they would have reacted in the same way as any of us. It is a general principle of his cognitive psychology that "all kinds of uncertainty have a strong connexion with fear" (T, 2.3.9.27; SBN, p. 446). Human beings typically experience fear and anxiety in the face of contingency, and given the extreme situation in which our ancestors found themselves, they must have been absolutely terrified.

This fear and anxiety would have motivated our ancestors to start thinking about the hidden forces that controlled their fates. But they lacked the cognitive capacities, as we all do, to entertain positive ideas of these secret powers. They could only refer to these unknown causes through the relative idea of that which distributes good and bad fortune:

We are placed in this world, as in a great theatre, where the true springs and causes of every event are entirely concealed from us; nor have we either sufficient wisdom to foresee, or power to prevent those ills, with which we are continually threatened. We hang in perpetual suspence between life and death, health and sickness, plenty and want; which are distributed amongst the human species by secret and unknown causes, whose operation is often unexpected, and always unaccountable. (NHR, p. 140)

Our ancestors might have recognized, in other words, that dark clouds are usually followed by rain. But they were not in an epistemic position to understand why this is the case. The ultimate nature of causation is simply beyond our power of comprehension.

It would not have been very satisfying, of course, to acknowledge ignorance about these matters. There is small consolation in the notion that our fate and fortune depend on something we know not what. Indeed, our ancestors would have abandoned reflection on such topics, according to Hume, were it not for a 
"propensity of human nature, which leads into a system that gives them some satisfaction” (NHR, p. 141):

There is a universal tendency among mankind to conceive all beings like themselves, and to transfer to every object, those qualities, with which they are familiarly acquainted, and to which they are intimately conscious. We find human faces in the moon, armies in the clouds. (NHR, p. 141; see also Guthrie, 1993, pp. 186-187)

The claim that human beings are prone to anthropomorphism is grounded in the cognitive psychology of the Treatise. Hume takes himself to have discovered a "remarkable inclination in human nature" to personify the natural world: children beat the stones that hurt them; poets project their feelings onto external objects; and even the wisest among us, such as our ancient philosophers, attribute occult faculties to inanimate matter ( $\mathrm{T}, 1.4 .4 .11$; SBN, p. 224).

Hume maintains that our passions and imagination are "equally employed" in the development of folk religious belief (NHR, p. 140). Our ancestors came to personify the hidden forces of nature, on his account, because it served to alleviate their fear and anxiety in the face of uncertainty:

No wonder, then, that mankind, being placed in such an absolute ignorance of causes, and being at the same time so anxious concerning their future fortune, should immediately acknowledge a dependence on invisible powers, possessed of sentiment and intelligence. (NHR, p. 142; see also NHR, p. 152)

The crucial point is that ontological commitment to supernatural agents provides us with an illusion of control over our future welfare. If the unknown powers which distribute good and bad fortune are similar to ourselves, after all, they might be "flexible by gifts and entreaties" (NHR, p. 159; see also NHR, pp. 139-140). Clothing them in human dress opens up an imaginary space, in other words, in which they might be convinced to lean in our favor.

This proposal also accounts for the origin of sacrifice and prayer. Our ancestors engaged in supplication in order to influence the will of those "secret intelligent powers on whom our fortune is supposed entirely to depend" (NHR, p. 143; see also NHR, p. 146). These petitionary practices would have been subsequently reinforced, moreover, by our natural tendency to believe in personal control over chance outcomes. Hume observes that those who are frequently confronted with probabilistic scenarios, such as gamblers and sailors, are especially prone to these "superstitious apprehensions" (NHR, p. 142). This natural propensity would have prevailed among our primitive ancestors, therefore, who lived in conditions of extreme uncertainty.

Hume maintains that belief in gods and spirits is natural in the sense that it depends on fundamental principles of human psychology (NHR, p. 152). But this does not entail that such convictions can be reflectively endorsed. Indeed, he cites the widespread belief in invisible agents as an example of a natural but unreasonable belief:

One who is tormented, he knows not why, with the apprehension of specters in the dark, may, perhaps, be said to reason, and to reason naturally too: But then it must 
be in the same sense, that a malady is said to be natural; as arising from natural causes, tho' it be contrary to health, the most agreeable and most natural situation of man. (T, 1.4.4.1; SBN, pp. 225-226)

Our natural religious beliefs do not share the same epistemic status, then, as our ordinary beliefs in causes and objects (Butler, 1960, pp. 87-88; Gaskin, 1988, pp. 120123). Human beings cannot live without these latter beliefs; they are necessary as well as natural (T, 1.4.4.1; SBN, p. 225). But the same cannot be said of our inclination to personify the secret powers of nature. This "Propensity of the Mind," Hume wrote to Gilbert Elliot, "may \& ought to be controul'd \& can never be a legitimate Ground of Assent” (LE, p. 26).

Hume makes it clear in the Natural history of religion that our folk religious beliefs are normatively inadequate. He describes them at various points as "ludicrous" (NHR, p. 146), "mistakes” (NHR, p. 151), “gross misconceptions" (NHR, p. 152), "irrational" (NHR, p. 154), "fictions" (NHR, p. 173), and "groundless" (NHR, p. 176). But Hume is less explicit about the grounds of this epistemic critique. The worry cannot be that our natural religious beliefs are founded on our faculty of imagination rather than reason; after all, this is true of all our fundamental beliefs about the world (T, 1.4.4.1; SBN, p. 225). What has Hume discovered about the recurrent belief in gods and spirits, then, which raises such serious doubts about its legitimacy? What does the debunking, as it were, in his account?

The main problem with our natural religious beliefs, according to Hume, is that they are responsive to passions rather than evidence. Let us distinguish two senses in which passions can motivate our enquiries: (a) they can prompt them; or (b) they can bias them. The first type of motivated reasoning is unproblematic. Someone might be moved to find a cure for a disease, for example, by virtue of their fear of succumbing to it. The influence of passions is only troublesome when they bias or distort our reasoning. But this is precisely what happens in the case of our folk religious beliefs. We ought to proportion our beliefs, in conditions of uncertainty, to the evidence available to us ( $\mathrm{T}, 1.3 .13 .1$; SBN, p. 143). We fail to live up to this standard, however, when we accept the existence of invisible agents.

Kail illustrates Hume's epistemic critique with the example of a wife who believes that her husband is faithful, in spite of the fact that he frequently returns home late from the office, smelling of perfume, with lipstick on his collar, etc. This is a classic example of self-deception: it is the sheer awfulness of the truth which prevents her from accepting it (Kail, 2007, p. 199). But this type of motivated irrationality serves as an inappropriate model for understanding Hume's natural history of religion. One cannot engage in self-deception, on standard analyses, unless one ignores or subverts contrary evidence. Hume does not claim, however, that our ancestors repressed or sublimated any uncomfortable facts. The problem is not, then, one of bad faith.

The trouble with belief in supernatural agents, rather, is that it is based on wishful thinking. One engages in wishful thinking when the desire that propositional content $\mathrm{p}$, or fear that $\sim \mathrm{p}$, causes one to believe that $\mathrm{p}$ (Johnston, 1988, p. 66). Consider a standard example: a student jumps to the conclusion that his feelings are reciprocated when his beloved says hello while passing in the hallway. The worry is that this person 
should, by parity of reasoning, be enamored with half the school (Szabados, 1973, p. 205). Wishful thinking can also be motivated by the desire to alleviate fear and anxiety. Patients who are terrified of mortal illness, for example, might interpret their symptoms in reassuring ways (Scott-Kakures, 2001, p. 313). This is precisely the manner in which our ancestors, according to Hume, arrived at their ontological commitment to gods and spirits. They did not come to believe in supernatural agents on the basis of evidence; rather, they did so because it mitigated their "anxious concern" in the face of uncertainty (NHR, p. 152).

Hume's main project in the Natural history of religion is to discover the principles of human nature that give rise to our folk religious beliefs. But he does not only want to understand why we believe what we do; he also wants to determine whether we believe what we should. The crucial issue is whether our natural religious beliefs can be reflectively endorsed. Given the results of his investigations, however, it is difficult to see how they could. Hume traces the widespread belief in supernatural agents back to biases and illusions of the imagination. When his descriptive account brings to light the source of these beliefs, then, it gives rise to skeptical doubts about their legitimacy (Gaskin, 1988, p. 187).

\section{Evaluating Hume's Proposals}

One might worry that it is difficult to assess Hume's proposals. We have no direct evidence, after all, concerning the origin of religious belief. Such events occurred long before our historical records. It would appear that we cannot make any meaningful statements about these matters, therefore, since there are no observations that could either confirm or falsify them. Any natural history of religion, as Dugald Steward famously put it, must be entirely conjectural.

This pessimistic attitude, however, is unjustified. We cannot observe what took place in our ancestral environment. But we can make reasonable inferences about the foundations of religious belief by carefully examining our psychological responses when placed in similar circumstances. Are we vulnerable to illusions of control in the face of uncertainty? Do we have a propensity to anthropomorphize when ignorant about causality? Hume's proposals are grounded, as we have seen, in the principles of his cognitive psychology. The plausibility of his natural history of religion ultimately depends, therefore, on the accuracy of his science of human nature.

This presents a serious challenge for historians of philosophy. Hume offers a number of empirical claims about our biases and propensities. We cannot determine the adequacy of these proposals, then, from the comfort of our armchairs. We must evaluate them, rather, in light of our best available evidence. Fortunately, we are currently in a position to do so. There are several decades of interdisciplinary research on motivated reasoning and our psychological responses to uncertainty. These studies enable us to make an informed judgment about the merits of Hume's account. It turns out that Hume's natural history of religion, moreover, fares quite 
well when put to the empirical test. Indeed, each of the propensities that he describes has been confirmed by psychological experiments and anthropological fieldwork:

1. There are a large number of studies which indicate that human beings are vulnerable to wishful thinking (Kruglanski, 1996; Kunda, 1990). We have a strong tendency to see ourselves, for example, as better than average (Alicke, 1985). Only 2\% of American high school seniors believe they are below average; and this bias is not limited to students: $94 \%$ of college professors claim that they are above average at their jobs (Gilovich, 1991). Interestingly, we also have a proclivity to think that we are better than average in terms of our capacity to avoid wishful thinking (Friedrich, 1996). This line of research provides considerable support for Hume's proposal, then, that human beings have a natural propensity to believe what we desire to be true.

2. A variety of experiments have corroborated Hume's claim that we are susceptible to illusions of control in conditions of uncertainty (Thompson, Armstrong, \& Thomas, 1998). Gamblers often believe that they have personal control, for example, over objectively chance outcomes (Henslin, 1967; Langer, 1975). We are especially prone to such biases, moreover, when anxious or stressed (Friedland, Keinan, \& Regev, 1992). Studies have also revealed that we often compensate for our perceived lack of control by imaginatively aligning ourselves with powerful external agents (Rothbaum, Weisz, \& Snyder, 1982). Indeed, individuals report stronger belief in a "supernatural controlling influence" when placed in situations where they lack personal control over events (Kay, Gaucher, Napier, Callan, \& Laurin, 2008, p. 23).

3. There is emerging evidence in social psychology that we are liable to anthropomorphize in unpredictable situations. Researchers have developed an experimental protocol that enables them to manipulate levels of uncertainty and measure its influence on our tendency to project human characteristics onto nonhuman domains. These studies have shown that we are more likely to personify objects when they act in erratic ways. Subjects demonstrated a greater tendency to attribute mental states, for example, to cars and computers that malfunction than those that do not (Morewedge, Preston, \& Wegner, 2007, p. 4). Participants were also more likely to attribute humanlike personalities to dogs and electronic gadgets that behave in a random manner (Epley, Waytz, \& Cacioppo, 2008, pp. 873-874). This research confirms Hume's proposal, then, that we have a propensity to anthropomorphize in the face of contingency.

4. There is considerable evidence from anthropological fieldwork that we are vulnerable to superstition when confronted with uncertain outcomes. Israeli citizens vulnerable to missile attacks in the first gulf war, for example, reported a greater number of superstitious beliefs than those who were not (Keinan, 2002). Similar reactions were found in American college students who took tests or competed in athletic events (Felson \& Gmelch, 1979; Rudski \& Edwards, 2007). Athletes are especially prone, it seems, to this type of magical thinking: three-quarters of professional baseball players in the U.S. and Japan engage in superstitious practices before games (Burger \& Lynn, 2005). 
In summary, Hume's proposals about our psychological biases and propensities receive a good deal of support from recent work in the social sciences. His science of human nature was based on informal observations of the behavior of those around him. But his claims have been corroborated by careful studies that employ quantitative measures, controlled experiments, and fieldwork protocols.

\section{Cognitive Science of Religion}

Hume's account has been challenged by contemporary researchers in the "cognitive science of religion." These theorists embrace Hume's general strategy of explaining the development of religious belief in terms of the principles of human nature (Boyer, 1994, p. xv). They also share Hume's particular emphasis on anthropomorphism. ${ }^{2}$ Cognitive scientists of religion take issue with Hume's proposal, however, that our natural religious beliefs are motivated by passions. Such convictions rest primarily, they maintain, on cognitive principles. ${ }^{3}$ Guthrie (1993, p. 90) argues that that these ontological commitments, for example, depend on our propensity to over-attribute human agency. Barrett defends a similar position: belief in invisible agents derives from a "hyperactive agency detection device" (2004, p. 32). Boyer proposes that the cultural recurrence of these commitments is grounded in basic features of human categorization, memory, and attention (1994, p. 60; 2001, p. 135; Pyysiäinen, 2009, pp. 28-30). Alternatively, Bering maintains that our folk belief in supernatural agents is based on "cognitive constraints" in our simulations of others minds (2006b, p. 455).

These approaches fail to provide a complete account, however, of our natural belief in gods and spirits. Consider Guthrie's proposal. Our ancestors lived in a dangerous and uncertain world full of ambiguous signals-noises in the dark, rustling leaves, and other things that go bump in the night. Those with a psychological propensity to interpret such cues as indicators of intelligent agents, he argues, would have an evolutionary advantage over those who lack it (Barrett, 2000, p. 31; Guthrie, 2001, p. 99). Better safe, in other words, than sorry:

In the face of chronic uncertainty about the nature of the world, guessing that some thing or event is humanlike or has a human cause constitutes a good bet. It is a bet because in a complex and ambiguous world our knowledge is always uncertain. It is a good bet because if we are right, we gain much, while if we are wrong, we usually lose little. (Guthrie, 1996, p. 417)

This suggestion, however, is implausible. It might have been adaptive for our ancestors to assume that crackling sounds in bushes are caused by potential predators. But this does not adequately explain why they came to believe in supernatural agents. The proposal that our ancestors traced ambiguous signals to the influence of gods and spirits, after all, presupposes their ontological commitment to the existence of invisible beings.

A similar point can be made about Boyer's proposal. He challenges the orthodoxy in anthropology that anthropomorphism is pervasive because it is intuitive. Boyer 


\section{M. Collier}

makes precisely the opposite claim: supernatural agents are culturally recurrent because they are counterintuitive (Boyer, 1996, p. 95). Concepts are favored in cultural transmission, on his account, when they violate one of two assumptions of our intuitive ontology. Consider the concept GHOST, for example. Ghosts are similar to ordinary persons, but they lack material bodies, and thus can walk through walls, etc. These minimal deviations from our intuitive category PERSON entail that ghost stories are novel enough to be attention-grabbing, yet familiar enough to support robust inferences.

This proposal appears to have solid empirical footing. Cross-Cultural studies have demonstrated that narratives about supernatural beings are easier to recall than those which involve ordinary persons (Boyer \& Ramble, 2001; Norenzayan, Atran, Faulkner, \& Schaller, 2006). It also receives support from a statistical analysis of the Roman Prodigy list: 99\% of the portents reported to Roman officials from 218 to 22 BCE involved minimally counterintuitive events (Lisdorf, 2001). But it fails to provide an exhaustive account of folk religious belief. We do not make an ontologically commitment, after all, to every minimally counterintuitive being. Why is there widespread belief in gods and spirits, then, but not other imaginary agents? ${ }^{4}$

Boyer attempts to resolve this difficulty by appealing to practical considerations. Gods and spirits are invisible beings and thus would have unrestricted access to strategic information (Boyer, 2000, p. 207). This unique property is what accounts for their selective advantage over other supernatural agents.

That a full-access agent is imagined to be around changes the value and possible outcome of possible courses of events and of intended courses of action. In most situations of social interaction, we need access to other people's actions and intentions, but we also need to protect ourselves by broadcasting only a certain description of our own intentions and actions. A strategic agent typically sees through all this and has access to real actions and intentions rather than the public version. (Boyer, 2000, p. 210)

Gods and spirits can, as it were, watch us in the dark. Concepts of these minimally counterintuitive beings are "particularly relevant" to our social lives, therefore, in the sense that they can monitor and enforce social cooperation (Boyer, 2000, p. 210; 2001, pp. 165 \& 167).

This proposal, however, puts the cart before the horse. We must believe in the existence of full-access agents before they could possibly influence our practical deliberations. But the ontological commitment to supernatural agents is precisely what stands in need of explanation. And it is here that Hume's hypothesis gains the advantage. Hume agrees with Boyer that reports of prodigies grab our attention (NHR, p. 136; SBN, p. 120; T, 1.3.10.4). He then goes one step further and explains the credence we put in powerful, invisible beings in terms of motivated reasoning. We do not merely imagine that there are supernatural agents that can enter into social exchanges with us; we believe in their real existence because we are anxious about our uncertain fates and hope that these beings might safeguard our futures. 
Bering maintains that his simulation constraint hypothesis avoids the problems with Boyer's account. Our natural belief in supernatural agents is not derived, on this proposal, from cultural exposure to counterintuitive tales; rather, it is based on innate constraints in the representational structures of human cognition (Bering, 2002, pp. 268-269). We come to understand other minds, according to Bering, by projecting ourselves into their shoes. This imaginative procedure serves to explain why we intuitively believe in personal survival after death. It is "epistemologically impossible" to simulate, after all, the complete absence of conscious states (Bering, 2002 , p. 272; 2006b, p. 455). We have a natural propensity to believe in ghosts and spirits, therefore, because we cannot imagine what it is like to be psychologically annihilated.

There are several problems, however, with this proposal. The first is that it appears to be circular. We attempt to simulate the content of other minds, after all, only if we antecedently believe that they exist. Imagining what it is like to be dead, therefore, assumes prior commitment to the afterlife (Antony, 2006, p. 462). Bering's account is also vulnerable to a contemporary version of Lucretius' "symmetry argument." We cannot imagine the complete absence of mental states prior to birth any more than we can imagine their complete absence after death. Belief in previous lives is not as culturally pervasive, however, as belief in personal survival after death. Bering's simulation-constraint hypothesis cannot explain, then, this asymmetry in our ontological commitments (Hodge, 2011, p. 398).

There is a sense in which Hume might have been pleased, in any case, with the proposals of those in the cognitive science of religion. It appears that their accounts support skeptical conclusions, after all, about the reasonableness of our natural religious beliefs. This inference has been challenged by several writers (Barrett, 2007; Murray, 2007). But it is hard to see how one can block it. If the spread of such commitments lies with our tendency to over-attribute agency, as Guthrie and Barrett maintain, then we should distrust them, since they are based on unreliable belief-formation mechanisms. Skeptical doubt would also be appropriate if the cultural transmission of religious ideas derives, as Boyer would have it, from our propensity to believe stories that violate our intuitive ontology; this is reason to disbelieve such reports, after all, rather than embrace them. The same could be said, finally, about Bering's proposal. Simulation constraints give rise, on his account, to systematic "illusions" and "errors" (Bering, 2006b, pp. 454-455). Folk beliefs in supernatural agents are natural, according to Bering, but they are also "disarmingly irrational" (Bering, 2006a, p. 145) and "fantastically illogical" (Bering, 2011, p. 125).

One of the central claims of cognitive science of religion is that belief in gods and spirits depends upon "ordinary" principles of human cognition (Barrett, 2000, p. 29; Boyer, 1994, pp. 91-92; Guthrie, 1980, pp. 185-187). But the crucial epistemic question concerns the trustworthiness of these psychological mechanisms. Hume debunks our folk beliefs in supernatural beings by tracing them back to wishful thinking and illusions of control. Researchers in the cognitive science of religion do so by showing how the propagation of such ideas depends 
on misfiring devices and human credulity. These alternative proposals, then, arrive at the same despairing conclusion.

\section{First Objection: "Frightening Gods"}

Hume maintains that ontological commitment to gods and spirits is based on motivated reasoning: the belief that we can influence the will of supernatural beings through petition and prayer serves to reduce anxiety about our fates. But this proposal faces an important challenge. The problem is that many folk religious beliefs are disturbing rather than comforting (Boyer, 2001, p. 143; Guthrie, 1993, pp. 74-76). Consider the spiritual beliefs, for example, of the Carajá Indians in Brazil:

The earth and underworld are inhabited by supernaturals .... There are two kinds. Many are amiable and beautiful beings who have friendly relations with humans... others are ugly and dangerous monsters who cannot be placated. Their woods are avoided and nobody fishes in their pools. (Lipkind, 1940, p. 249; quoted in Atran, 2002, p. 69)

It is hard to see how Hume's account could handle belief in malevolent demons, diabolical sorcerers, and the like. After all, these beings appear to increase, rather than mitigate, our fear and anxiety.

The Caraján belief in evil spirits is an instance of what contemporary philosophers call "unwelcome belief" (Barnes, 1997; Scott-Kakures, 2000). Consider a paradigmatic example: a husband comes to believe, without a shred of evidence, that his wife is unfaithful. It is difficult to explain this type of belief in terms of wishful thinking. One engages in wishful thinking when one comes to believe that $\mathrm{p}$ because one hopes that $\mathrm{p}$ or fears that $\sim \mathrm{p}$. But the jealous husband example does not fit this mold. Quite the contrary, he comes to believe that $p$ even though he hopes that $\sim p$ and fears that $p$. Cases such as these strike one as perverse. We can sympathize with the student who jumps to the conclusion that his affections are reciprocated; it is difficult to make any sense, however, of the husband who brings such intense misery upon himself.

Barnes attempts to accommodate such cases to a "two-variable" account of motivated reasoning. Unwelcome beliefs that $\mathrm{p}$ are intelligible, she maintains, if we anxiously fear that $\sim \mathrm{q}$ and believe that $\mathrm{p}$ entails $\mathrm{q}$ (Barnes, 1997, p. 36). Barnes accounts for the jealous husband example, for example, by drawing from the plot of Shakespeare's The winter's tale. Suppose that a husband fails to convince his childhood friend of something but his wife easily succeeds in doing so. The husband might come to believe they are having an affair, according to Barnes, because it alleviates his anxiety that his wife's opinions are taken more seriously than his own (1997, p. 41). This is not to deny, of course, that believing in his wife's infidelity is anxiety-producing. The point is merely that it might serve to reduce his greater discomfort about his self-worth. 
This two-variable framework can be applied to the case of frightening gods. Consider the Caraján commitment to dangerous supernatural beings living in the woods. Let us assign these values to the following variables.

$\mathrm{p}=$ frightening gods who live in the woods

$\mathrm{q}=$ enter the woods at night

Suppose that the Carajáns have an intense fear of entering the woods at night. The unwelcome belief that $\mathrm{p}$ would be anxiety-reducing, then, as long as it gives one reason not to q. This explanatory schema would cover every instance in which ontological commitment to frightening gods, all things considered, serves to mitigate worse terrors.

\section{Second Objection: "Positive Illusions"}

Hume objects to illusions of the imagination on the grounds that they are "contrary to health" and are not "useful in the conduct of life" (SBN, pp. 225-226; T, 1.4.4.1). Recent work in social psychology, however, appears to contradict these claims. Studies have shown that motivated reasoning often helps us care about others and engage in productive work. It is often beneficial to our wellbeing, moreover, by preventing depression and learned helplessness (Haidt \& Rodin, 1999, pp. 326-328; Taylor \& Brown, 1988). This line of research supplies the basis for an objection to Hume's critique of folk religion. Belief in supernatural agents might depend on wishful thinking and illusions of control. But evidentially unwarranted beliefs are often highly adaptive. They are, in contemporary terms, positive illusions.

One might respond to this objection by questioning the utility of motivated reasoning. Inaccurate beliefs enable us to persevere at difficult tasks, for example, but they also make us liable to escalate failing courses of action (Whyte, Saks, \& Hook, 1997). Students with unrealistic notions of their academic abilities, moreover, often wind up disengaged from school; the problem is that their teachers and peers do not share their inflated assessment of their talents and abilities (Paulhus, 1998; Robins \& Beer, 2001). Indeed, motivated beliefs can sometimes have extremely dangerous consequences: college students with illusions of control over HIV susceptibility, for example, are less likely to take protective measures during intercourse (Thompson, Kent, Thomas, \& Vrungos, 1999).

Motivated reasoning could also block us from taking actions that actually contribute to our happiness. Consider once again the self-deceiving wife. Believing that her husband is faithful, even in the teeth of abundant counterevidence, prevents the onset of depression and learned helplessness; but it would also stop her from doing anything to change the awful situation in which she finds herself. Similar worries can be raised about our folk religious beliefs. Illusions of control over the secret powers of nature bring immediate pleasures to those in conditions of uncertainty. But they do not in fact make our futures more secure. And they might also prevent us, as Paul Russell points out, from "taking measures that are truly necessary to satisfy our needs and keep our 
fears and anxieties at bay" (Russell, 2008, p. 295). The short-term benefits of illusions of control, it seems, are outweighed by their long-term costs.

The jury is still out on this question. There is considerable evidence that religiosity-including belief in the efficacy of prayer-is associated with positive health and longevity (Koenig, McCullough, \& Larson, 2001). But it remains to be seen whether these benefits depend on belief in supernatural agents rather than other confounding factors (Sloan, Bagiella, \& Powell, 1999, p. 665). Those who are ontologically committed to gods and spirits are more likely to attend religious services, for example, and the social support that comes along with these communal activities might independently promote health and wellbeing (Strawbridge, Shema, Cohen, \& Kaplan, 2001, p. 72).

There might also be significant opportunity costs connected with illusions of control over invisible beings. These costs-measured in time and energy-are typically minimal. But they could, in some cases, be extreme. Patients have been known to forego vital medical procedures, for example, due to confidence that their prayers will be answered (Asser \& Swan, 1998, pp. 626-627). The precise number of child deaths due to belief in faith healing is currently unknown (Asser \& Swan, 1998, p. 628). This introduces a great deal of indeterminacy in any cost-benefit analysis of our natural propensity to believe that we can influence the wills of gods and spirits. Such commitments might prove, in the end, to be practically beneficial. But further studies are required to measure their overall utility.

\section{Conclusion}

Philosophers have traditionally cited the ubiquity of religious belief as grounds from which one can infer the truth of theism. But this argument depends on the assumption that the cultural recurrence of these commitments must be explained in religious terms (Yandell, 1990, pp. 119-120). Hume offers a reductive account of religious thought, however, which does not posit the existence of any supernatural entities. This proposal blocks the inference, then, from universal assent to realism about gods and spirits.

Hume's investigations also raise skeptical worries about the status of our natural religious beliefs. His main project in the Natural history of religion is to discover the principles of human nature responsible for our folk belief in gods and spirits. But this project is not purely descriptive in character; it also has serious normative consequences. Hume discovers that the pervasive belief in supernatural agents depends on wishful thinking and illusions of control. When his science of human nature reveals the causes of these beliefs, therefore, it provides us with prima facie reasons to doubt their legitimacy.

One must be careful not to exaggerate, however, the skeptical import of this claim. Hume's critique is aimed at the species of "false religion" which so thoroughly populate the world (DNR, p. 126; S\&E, p. 74). But this leaves the door open to the possibility that a "genuine" version of theism, purged of any anthropomorphic biases 
and illusions of control, might nevertheless emerge as philosophically defensible (Falkenstein, 2003, p. 4). The challenge for proponents of this rational reconstruction is to explain how they avoid the fallacies that permeate our natural beliefs (Bell, 1999, p. 160; LE, p. 26). This ameliorative strategy runs the risk, moreover, of collapsing into a version of deism that is devoid of any religious significance (DNR, p. 72). Theists are left to steer a path, in the end, between the horns of this dilemma.

\section{Notes}

[1] In what follows, I will use the following abbreviations for Hume's works: "Of superstition and enthusiasm" (Hume, 1987) as S\&E; "Dialogues concerning natural religion” (Hume, 1998a) as DNR; "Letter to Elliot" (Hume, 1998b) as LE; Natural history of religion (Hume, 1998c) as NHR; A treatise of human nature (Hume, 2002) as T; and the Selby-Bigge edition of A treatise of human nature (Hume, 1978) as SBN.

[2] Indeed, cognitive scientists of religion have thrown a good deal of light on this traditional topic. They have carefully documented the extent to which commitment to supernatural agents, for example, permeates contemporary religious rituals (McCauley \& Lawson, 2002) and petitionary prayers (Barrett, 2002). They have also conducted laboratory experiments which reveal that those who officially believe that anthropomorphism is "theologically incorrect" nevertheless engage in this type of reasoning when performing on-line tasks (Barrett \& Keil, 1996, p. 242). Subjects in these experiments reported that God would answer one prayer before another, even though this is inconsistent with their explicit beliefs about God's unchanging nature.

[3] This is not to say that the emotions are considered irrelevant in the cognitive science of religion. The passions play a "minimal role" in the epidemiology of belief in supernatural agents, but they have a prominent place in explanations of religious ritual (Cohen, Lanman, McCauley, \& Whitehouse, 2008, p. 113; McCauley \& Cohen, 2010, p. 781).

[4] The "Mickey Mouse problem" was initially discussed by Boyer as a possible objection to his account (Boyer, 2000, p. 202; 2001, p. 136). It was subsequently discussed by Atran and others (Atran, 2002, p. 14; Bulbulia, 2004, pp. 662-663). Atran objects to cognitive theories of religion on the grounds that they cannot explain why some counterintuitive agents (Zeus, Vishnu) become the objects of devotion, worship, and sacrifice, whereas other counterintuitive agents (Mickey Mouse) do not. Gods and spirits are culturally transmitted, according to Atran, because they help to resolve existential anxieties about death and deception (Atran, 2006, p. 186; Atran \& Norenzayan, 2004, pp. 726-728). This emphasis on the passionate motivators of religious belief lands Atran and his colleagues squarely in the Humean camp.

\section{References}

Alicke, M.D. (1985). Global self-evaluation as determined by the desirability and controllability of trait adjectives. Journal of Personality and Social Psychology, 49, 1621-1630.

Antony, M.V. (2006). Simulation constraints, afterlife beliefs, and common-sense dualism. Behavioral \& Brain Sciences, 29, 462-463.

Asser, S.M., \& Swan, R. (1998). Child fatalities from religion-motivated medical neglect. Pediatrics, $101,625-629$.

Atran, S. (2002). In gods we trust: The evolutionary landscape of religion. New York, NY: Oxford University Press. 


\section{M. Collier}

Atran, S. (2006). The cognitive and evolutionary roots of religion. In P. McNamara (Ed.), Where God and science meet: How brain and evolutionary studies alter our understanding of religion (pp. 181-207). Westport, CT: Praeger.

Atran, S., \& Norenzayan, A. (2004). Religion's evolutionary landscape: Counterintuition, commitment, compassion, and communion. Behavioral \& Brain Sciences, 27, 713-770.

Barnes, A. (1997). Seeing through self-deception. Cambridge: Cambridge University Press.

Barrett, J.L. (2000). Exploring the natural foundations of religion. Trends in Cognitive Sciences, 4, 29-34.

Barrett, J.L. (2002). Dumb gods, petitionary prayer, and the cognitive science of religion. In I. Pyysiainen \& V. Anttonen (Eds.), Current approaches in the cognitive study of religion (pp. 93-109). London: Continuum.

Barrett, J.L. (2004). Why would anyone believe in God? Walnut Creek, CA: Altamira.

Barrett, J.L. (2007). Is the spell really broken? Biopsychological explanations of religion and theistic belief. Theology and Science, 5, 57-72.

Barrett, J.L., \& Keil, F.C. (1996). Conceptualizing a non-natural entity: Anthropomorphism in god concepts. Cognitive Psychology, 31, 219-247.

Bell, M. (1999). Hume on superstition. In D.Z. Phillips \& T. Tessin (Eds.), Religion \& Hume's legacy (pp. 153-170). Basingstoke, UK: Macmillan.

Bering, J.M. (2002). Intuitive conceptions of dead agents' minds: The natural foundations of afterlife beliefs as phenomenological boundary. Journal of Cognition and Culture, 2, 263-308.

Bering, J.M. (2006a). The cognitive psychology of belief in the supernatural. American Scientist, 94, $142-149$.

Bering, J.M. (2006b). The folk psychology of souls. Behavioral \& Brain Sciences, 29, 453-498.

Bering, J.M. (2011). The belief instinct: The psychology of souls, destiny and the meaning of life. New York, NY: W.W. Norton.

Boyer, P. (1994). The naturalness of religious ideas: A cognitive theory of religion. Berkeley, CA: University of California Press.

Boyer, P. (1996). What makes anthropomorphism natural: Intuitive ontology and cultural representations. Journal of the Royal Anthropological Institute, 2, 83-97.

Boyer, P. (2000). Functional origins of religious concepts: Ontological and strategic selection in evolved minds. Journal of the Royal Anthropological Institute, 6, 195-214.

Boyer, P. (2001). Religion explained: The evolutionary origins of religious thought. New York, NY: Basic Books.

Boyer, P., \& Ramble, C. (2001). Cognitive templates for religious concepts: Cross-cultural evidence for recall of counter-intuitive representations. Cognitive Science, 25, 535-564.

Bulbulia, J. (2004). The cognitive and evolutionary psychology of religion. Biology and Philosophy, $19,655-686$.

Burger, J.M., \& Lynn, A.L. (2005). Superstitious behavior among American and Japanese professional baseball players. Basic and Applied Social Psychology, 27, 71-76.

Butler, R.J. (1960). Natural belief and the enigma of Hume. Archivfur die Geschicte der Philosophie, $42,73-100$.

Cohen, E., Lanman, J., McCauley, R.N., \& Whitehouse, H. (2008). Common criticisms of cognitive science of religion-answered. Bulletin of the Council of Societies for the Study of Religion, 37, $112-115$.

Epley, N., Waytz, A., \& Cacioppo, J.T. (2008). On seeing human: A three-factor theory of anthropomorphism. Psychological Review, 114, 864-886.

Falkenstein, L. (2003). Hume's project in 'The natural history of religion'. Religious Studies, 39(1), 1-21.

Felson, R., \& Gmelch, G. (1979). Uncertainty and the use of magic. Current Anthropology, 20, 587-589. 
Friedland, N., Keinan, G., \& Regev, Y. (1992). Controlling the uncontrollable: Effects of stress on illusory perceptions of controllability. Journal of Personality and Social Psychology, 63, 923-931.

Friedrich, J. (1996). On seeing oneself as less self-serving than others: The ultimate self-serving bias? Teaching of Psychology, 23, 107-109.

Gaskin, J.C.A. (1988). Hume's philosophy of religion. Basingstoke, UK: Macmillan.

Gilovich, T. (1991). How we know what isn't so: The fallibility of human reason in everyday life. New York, NY: The Free Press.

Guthrie, S.E. (1980). A cognitive theory of religion. Current Anthropology, 21, 181-203.

Guthrie, S.E. (1993). Faces in the clouds: A new theory of religion. New York, NY: Oxford University Press.

Guthrie, S.E. (1996). Religion: What is it?. Journal for the Scientific Study of Religion, 35, 412-419.

Guthrie, S.E. (2001). Why gods? A cognitive theory. In J. Andresen (Ed.), Religion in mind: Cognitive perspectives on religious belief, ritual and experience (pp. 94-111). Cambridge: Cambridge University Press.

Haidt, J., \& Rodin, J. (1999). Control and efficacy as interdisciplinary bridges. Review of General Psychology, 3, 317-337.

Henslin, J.M. (1967). Craps and magic. American Journal of Sociology, 73, 316-330.

Hodge, K.M. (2011). Why immortality alone will not get me to the afterlife. Philosophical Psychology, 24, 395-410.

Hume, D. (1978). A treatise of human nature (2nd ed.). Oxford: Clarendon.

Hume, D. (1987). Of superstition and enthusiasm. In E.F. Miller (Ed.), David Hume: Essays: Moral, political, and literary (pp. 73-79). Indianapolis, IN: Liberty Fund.

Hume, D. (1998a). Dialogues concerning natural religion. In J.C.A. Gaskin (Ed.), David Hume: Principal writings on religion (pp. 29-130). Oxford: Oxford University Press.

Hume, D. (1998b). Letter to Elliot. In J.C.A. Gaskin (Ed.), David Hume: Principal writings on religion (pp. 25-28). Oxford: Oxford University Press.

Hume, D. (1998c). Natural history of religion. In J.C.A. Gaskin (Ed.), David Hume: Principal writings on religion (pp. 134-185). Oxford: Oxford University Press.

Hume, D. (2002). A treatise of human nature. Oxford: Oxford University Press.

Johnston, M. (1988). Self-deception and the nature of mind. In B. McLaughlin \& A.O. Rorty (Eds.), Perspectives on self-deception (pp. 63-91). Berkeley, CA: University of California Press.

Kail, P.J.E. (2007). Understanding Hume's natural history of religion. Philosophical Quarterly, 57, $190-211$.

Kay, A.C., Gaucher, D., Napier, J.L., Callan, M.J., \& Laurin, K. (2008). God and the government: Testing a compensatory control mechanism for the support of external systems. Journal of Personality and Social Psychology, 95, 18-35.

Keinan, G. (2002). The effects of stress and desire for control on superstitious behavior. Personality and Social Psychology Bulletin, 28, 102-108.

Koenig, H.G., McCullough, L.A., \& Larson, D.B. (2001). Handbook of religion and health. New York, NY: Oxford University Press.

Kruglanski, A.W. (1996). Motivated social cognition: Principles of the interface. In E.T. Higgins \& A.W. Kruglanski (Eds.), Social psychology: Handbook of basic principles (pp. 493-520). New York, NY: Guilford.

Kunda, Z. (1990). The case for motivated reasoning. Psychological Bulletin, 108, 480-498.

Langer, E.J. (1975). The illusion of control. Journal of Personality and Social Psychology, 32, 311-328.

Lipkind, W. (1940). Carajá cosmography. Journal of American Folklore, 53, 248-251.

Lisdorf, A. (2001). The spread of non-natural concepts. Journal of Cognition \& Culture, 4, $151-174$.

McCauley, R.N., \& Cohen, E. (2010). Cognitive science and the naturalness of religion. Philosophy Compass, 5, 779-792. 
McCauley, R.N., \& Lawson, E.T. (2002). Bringing ritual to mind: Psychological foundations of cultural forms. Cambridge: Cambridge University Press.

Morewedge, C.K., Preston, J., \& Wegner, D.M. (2007). Timescale bias in the attribution of mind. Journal of Personality and Social Psychology, 93(1), 1-11.

Murray, M.J. (2007). Four arguments that the cognitive psychology of religion undermines the justification of religious belief. In J. Bulbulia, R. Sosis, E. Harris, R. Genet, C. Genet, \& K. Wyman (Eds.), Evolution of religion: Studies, theories, and critiques (pp. 365-370). Santa Monica, CA: Collins Foundation.

Norenzayan, A., Atran, S., Faulkner, J., \& Schaller, M. (2006). Memory and mystery: The cultural selection of minimally counterintuitive narratives. Cognitive Science, 30, 531-553.

Paulhus, D.L. (1998). Interpersonal and intrapsychic adaptiveness of trait self-enhancement: A mixed blessing? Journal of Personality and Social Psychology, 74, 1197-1208.

Pyysiäinen, I. (2009). Supernatural agents: Why we believe in souls, gods, and Buddhas. New York, NY: Oxford University Press.

Robins, R.W., \& Beer, J.S. (2001). Positive illusions about the self: Short-term benefits and long-term costs. Journal of Personality and Social Psychology, 80, 340-352.

Rothbaum, F., Weisz, J.R., \& Snyder, S. (1982). Changing the world and changing the self: A twoprocess model of perceived control. Journal of Personality and Social Psychology, 42, 5-37.

Rudski, J.M., \& Edwards, A. (2007). Malinowski goes to college: Factors influencing students' use of ritual and superstition. Journal of General Psychology, 134, 389-403.

Russell, P. (2008). The riddle of Hume's Treatise: Skepticism, naturalism, and irreligion. New York, NY: Oxford University Press.

Scott-Kakures, D. (2000). Motivated believing: Wishful and unwelcome. Nous, 34, 348-375.

Scott-Kakures, D. (2001). High anxiety: Barnes on what moves the unwelcome believer. Philosophical Psychology, 14, 313-326.

Sloan, R.P., Bagiella, E., \& Powell, T. (1999). Religion, spirituality, and medicine. The Lancet, 353, 664-667.

Strawbridge, W.J., Shema, S.J., Cohen, R.D., \& Kaplan, G.A. (2001). Religious attendance increases survival by improving and maintaining good health behaviors, mental health, and social relationships. Annals of Behavioral Medicine, 23, 68-74.

Szabados, B. (1973). Wishful thinking and self-deception. Analysis, 33, 201-205.

Taylor, S.E., \& Brown, J.D. (1988). Illusion and well-being: A social psychological perspective on mental health. Psychological Bulletin, 103, 193-210.

Thompson, S.C., Armstrong, W., \& Thomas, C. (1998). Illusions of control, underestimations, and accuracy: A control heuristic explanation. Psychological Bulletin, 123, 143-161.

Thompson, S.C., Kent, D.R., Thomas, C., \& Vrungos, S. (1999). Real and illusory control over exposure to HIV in college students and gay men. Journal of Applied Social Psychology, 29, $1128-1150$.

Whyte, G., Saks, A.M., \& Hook, S. (1997). When success breeds failure: The role of self-efficacy in escalating commitment to a losing course of action. Journal of Organizational Behavior, 18, $415-432$.

Yandell, K. (1990). Hume's inexplicable mystery. Philadelphia, PA: Temple University Press. 
Copyright of Philosophical Psychology is the property of Routledge and its content may not be copied or emailed to multiple sites or posted to a listserv without the copyright holder's express written permission. However, users may print, download, or email articles for individual use. 